\title{
Potential Migration Investigation in the Mechanism of Labor Market Regulation
}

\author{
Olha Ryndzak $^{1}$, Oleh Risnyy ${ }^{2} \&$ Mariana Bil $^{1}$ \\ ${ }^{1}$ State Institution "Institute of Regional Research named after M.I. Dolishniy of the National Academy of Sciences of \\ Ukraine", Ukraine \\ ${ }^{2}$ Lviv City Employment center, Ukrainian state Employment Service Training Institute, Ukraine \\ Correspondence: Olha Ryndzak, State Institution "Institute of Regional Research named after M.I. Dolishniy of the \\ National Academy of Sciences of Ukraine”, Kozel'nyts'ka street, 4, Lviv, 79026, Ukraine. Tel: 380-50-101-0846. \\ E-mail: olichkar@yahoo.com
}

Received: April 1, 2020

doi:10.5430/rwe.v11n3p80
Accepted: May 3, 2020

Online Published: June 16, 2020

URL: https://doi.org/10.5430/rwe.v11n3p80

\begin{abstract}
Effective regulation of labor market and elaboration of preventive policy measures requires proper information support. Such support can be provided by the investigation of not only real but also potential migration. This article provides the authors' complex approach to the study of a potential migration. In particular, three stages of potential migration are investigated on the basis of the results of a panel sample survey of unemployed in Lviv city, Ukraine (2013-2016, 2018-2019): migration desires, plans (decision) and preparations. Thus in 2019 the share of respondents having positive migration desires made up 56\%, planning to move abroad $-26 \%$ and only $18 \%$ made some preparations for moving. Based on the results obtained during six years of study a map of migration preferences is made. So Germany, the USA and Canada are mostly chosen for permanent residence or long time migration. Poland and Germany are the most desired for temporary work. Based on the logistic regression model the impact of gender and age on decision regarding employment abroad is showed. Respondents' estimations of their financial situation and employment opportunities in relation to their potential migration are also analyzed. Presented in the article study may be replicated in other regions and other samples may be used for survey. It would allow comparative analysis of potential migration between different groups and regions and would be helpful for policy making.
\end{abstract}

Keywords: migration, potential migration, unemployed, migration desires, labor market, Ukraine

JEL Classification: F22, J61, J68

\section{Introduction}

Globalization and free movement of labor force across borders, observed before the spreading of COVID-2019, had a strong impact on national labor markets. It often happens that international temporary labor migration transforms in permanent one. So countries of origin suffer of shortage of workers of certain skills and human potential migration losses as well. Ukraine is one of such countries. According to the data of United Nations general number of emigrants from Ukraine amounted to 5.9 million persons in 2019 (UN, 2019). It requires elaboration of preventive measures of migration policy and new approaches to labor market regulation. The scientific basis for it should be investigation of not only real but also potential migration.

There are a few studies devoted to theoretical and methodological aspects of exactly potential migration investigation (Carling, 2002; Carling \& Collins 2018; Rybakovkiy, 2001; Ryndzak, 2019).

Regarding the empirical studies, migration intentions around the world were investigated in the joint project between the Directorates of the European Commission and the OECD. The study analyses the attractiveness of the European Union for potential migrants and describes the socio-demographic portrait of them (Gubert \& Jean-Noël, 2016). Potential migration is explored in different countries using different methods. For example, future trends in migration from Albania were designed on the basis of migration intentions investigation (King \& Gëdeshi, 2019). The qualitative assessment of probable migration from North Africa to OECD Countries (based on experts' considerations) was made by the French scientists (Gubert\&Nordman, 2009). Influence of different measures of migration policy on immigration flows is studied in Japan using mathematical modelling (Fujita, 2018). Besides, 
studies on main drivers of international migration are popular now (for example, Migali et al, 2018; Gheasi \& Nijkamp, 2017; Grenčíková \& Španková, 2016).

The Gallup International Association estimates regularly the number of permanent potential migrants. Its estimation is based on the expressed desire of adults to migrate permanently if they could (Esipova et al., 2011).

Economists have conducted complex analysis of the existing migration flows and processes (Libanova, 2019). A lot of researches dedicated to immigration's impact on labor market (Edo, 2019; Sumption \& Somerville, 2009; Vandenbroucke \& Zhu 2017), its contribution to welfare and income in host countries (Krutova, 2019). But potential migration is out of focus and is not researched enough.

Thus, existing potential migration investigations cover only some aspects of this problem and are mostly made by international organizations or sociological institutions. The importance for potential migration researches is underestimated in the current economic literature. As recent studies show, the most important reasons for the international migration (actual for Ukraine and for many other counties) are: insufficient development of the national labor market with high unemployment and poor employment opportunities; imperfect wage system (Marchuk, 2011). So studies of potential migration should be conducted in connection with labor market regulation.

The aim of the article is to present the authors' complex approach to potential migration investigation as an important information component in the mechanism of labor market regulation. The presentation is based on the sociological panel survey (2013-2016, 2018-2019). The time span chosen contains very important political and social events in Ukraine: the war in the east of the country (started in 2014 to now); two presidential elections and new governments' formation (in 2014 and 2019). It influenced significantly on main economic performance. Thus the unemployment rate increased from 7.8\% (2013) to 9.7\% in 2014 and is still at this level (Minfin, 2019). Due to hryvnia devaluation in 2014 the average monthly wage in Ukraine decreased from 408 USD (2013) to 192 USD (2015). In 2016 it begun to increase slowly and in 2019 was 404USD (SSSU, 2020). All these things have reflected on the population's migration desires, plans and activity.

\section{Method}

In the broadest sense migration can be defined as territorial movement of population between administrative areas, localities within a country or across national borders, regardless of the purpose, duration or regularity (based on Denisenko et al., 1989, p.4-5). At the same time migration is a complex social, economic and psychological process that affects practically all aspects of human activities, society as a whole, causing changes in the structure of the economic system and the placement of the main factors of manufacturing in the country. The concept of migration is closely linked with migration processes. The migration process on a personal level is schematically depicted in Figure 1. In the case of voluntary migration, we follow the position of those authors who affirm that migration is mostly the result of unmet needs of the individual, limited opportunities for its fulfillment (Blinova, 2011, p.124). Next steps of an individual depend on his/her values, migration desires, as well as on variety of factors. Proposed scheme helps to distinguish between three main stages of potential migration: migration desires; migration decision, plans; migration preparations (shaded boxes on Figure 1). It can serve methodological basis for determination of three groups of potential migrants and for elaboration appropriate measures of migration policy and labor market regulation. We suppose that the share of those who have positive migration attitudes is the largest and the group preparing for migration is much smaller. 


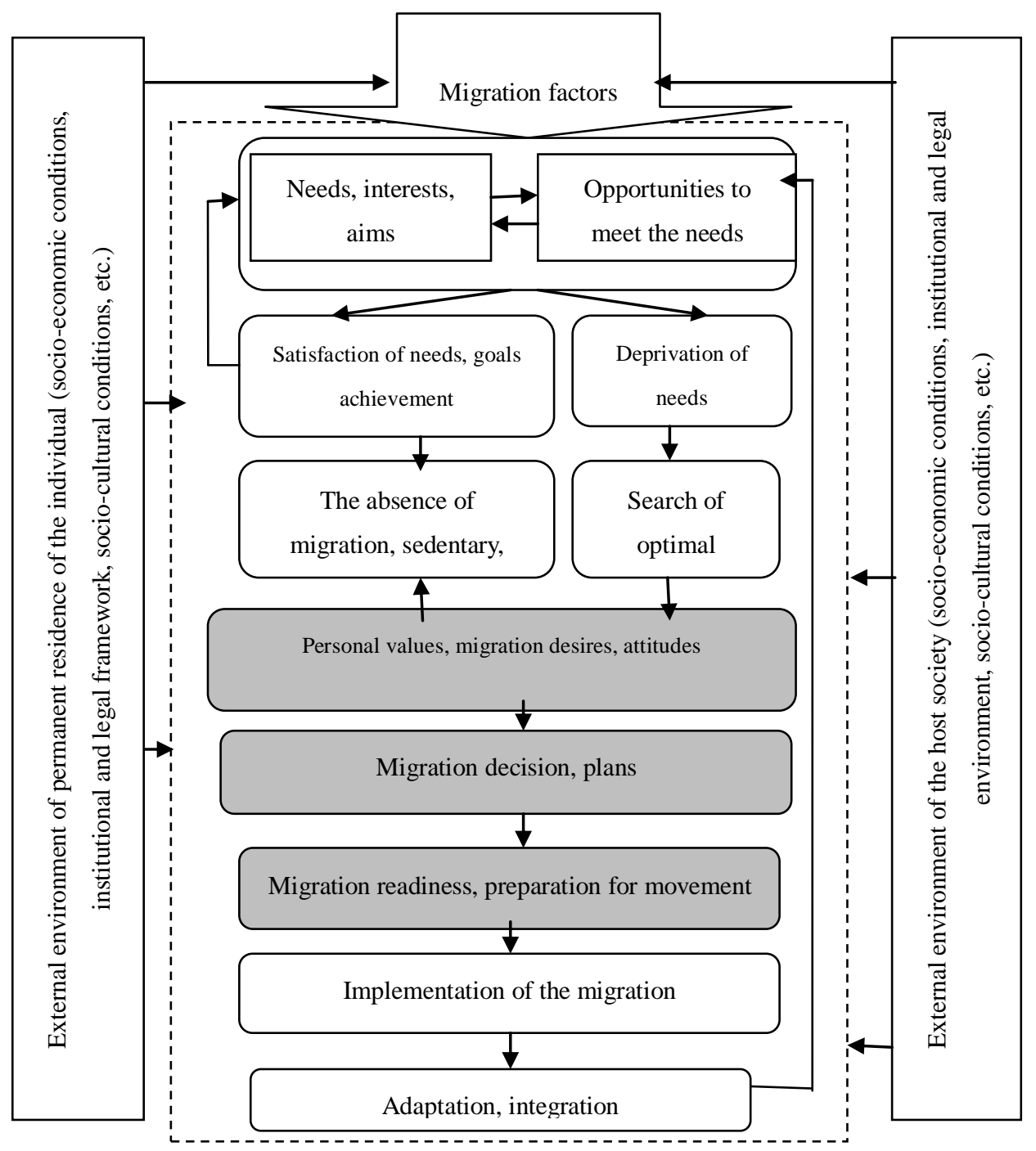

Figure 1. Migration process: personal dimension

Source: own elaboration (Ryndzak, 2016, p.87).

For demonstration of the authors' methodological approach to potential migration investigation the results of a sociological survey will be used. The research was conducted by the authors in the autumns of 2013-2016, 2018-2019. Every year 500 questionnaires were distributed among unemployed persons - visitors of the Lviv City Employment Center. A stratified sample was used. The major features of stratification are: gender, age and education.

We constructed a regression model based on one of the stages (2018) of a panel survey of the unemployed population of the Lviv region for a deeper investigation of the influence of the socio-demographic characteristics of a person on his/her decision regarding employment abroad. Since the dependent variable (the presence or absence of plans to find a job abroad) is presented in the nominal dichotomous type scale, the logistic regression method is applicable. In general, the equation of such a regression is as follows (Skog, 2010, p.358):

$$
P=\frac{1}{1+e^{-Y}}
$$

where $\mathrm{P}$ - is the predicted (or expected) Y-value;

$\mathrm{Y}$ is the linear regression equation: $Y=b_{o}+b_{1} x_{1}+b_{2} x_{2}+\ldots+b_{n} x_{n}$

$x_{i}$ - value of independent variables; $b_{i}$ - parameters of the regression equation; $b_{0}$-intercept term; $\mathrm{e}-$ the base of the 
natural logarithm, that is equal to 2.7182 .

To examine a relationship of respondents' migration plans with their estimations of employment opportunities on the national labor market we used $\chi^{2}$-test (Ringdal, 2007, p.278-281). Calculations are based on the results of the last stage of the survey (2019). The statistical hypotheses are:

$\mathrm{H}_{0}$ : There was no statistical relationship between unemployed persons' migration plans with their estimations of employment opportunities on the national labor market in 2019.

$\mathrm{H}_{1}$ : There was a statistical relationship between unemployed persons' migration plans with their estimations of employment opportunities on the national labor market in 2019.

\section{Results and Discussion}

In order to identify those, who have positive migration attitudes such question was asked: "If you had the opportunity, what would you prefer to do?" And several answers were proposed (Table 1). Thus, almost one-third of respondents would move abroad for permanent residence in 2013, but in 2019 they made up the fourth part of unemployed persons. The share of persons preferring moving abroad for a few years to improve financial situation remained almost changeless (17-19\%). The group of respondents who would move abroad for temporary work was the largest in $2018(21 \%)$ and the smallest - in 2013 (7.5\%). Generally, more than half of respondents expressed positive migration desires annually. It reflects global trends in the population's migration desires. For example, according to the Boston Consulting Group's international survey in 197 countries, more than half of respondents (57\%) would prefer to move to another country (Strack et al., 2018).

Table 1. Migration desires of the respondents, $\%$ of the number of observations

\begin{tabular}{lcccccc}
\hline \multicolumn{1}{c}{ Answers } & $\mathbf{2 0 1 3}$ & $\mathbf{2 0 1 4}$ & $\mathbf{2 0 1 5}$ & $\mathbf{2 0 1 6}$ & $\mathbf{2 0 1 8}$ & $\mathbf{2 0 1 9}$ \\
\hline Would move abroad for permanent residence & 32.2 & 23.8 & 31.4 & 21.3 & 23.4 & 24.7 \\
Would move abroad for a few years to improve financial situation & 17.2 & 17.5 & 18 & 18.6 & 16 & 18.8 \\
Would move abroad for temporary work & 7.5 & 11 & 10 & 13.6 & 21 & 12.8 \\
Would move abroad only for learning or entertaining experience & 14.7 & 16.5 & 12.3 & 12.7 & 13.9 & 16.7 \\
Would not move abroad & 29.2 & 29.8 & 26 & 33.2 & 24 & 26.6 \\
Not sure & 3.9 & 1.4 & 7.5 & 0.6 & 1.7 & 0.3 \\
\hline
\end{tabular}

Source: survey data, 2013-2016, 2018-2019.

When choosing the first three answer options (see Table 1), respondents had the opportunity to write in the country where they would go for temporary work, for a long time or for permanent residence. Based on the results obtained during six years of study, we compiled a ranking of countries according to the frequency of this choice for each year, thus forming a map of migration preferences for the unemployed population of Lviv region. So, people who wanted to go abroad for permanent residence or for a long time, chose mostly Germany, the United States and Canada (see table 2,3). According to the Gallup's research the USA is the most desirable country for potential migrants. Canada and Germany are also in the top-10 of the most attractive countries for potential migrants (Esipova et al., 2018).

Table 2. The most attractive countries for potential permanent migrants, $\%$ of the respondents who would move abroad permanently

\begin{tabular}{lccccccccccccc}
\hline \multirow{1}{*}{ Answers } & \multicolumn{2}{c}{$\mathbf{2 0 1 3}$} & \multicolumn{2}{c}{$\mathbf{2 0 1 4}$} & \multicolumn{2}{c}{$\mathbf{2 0 1 5}$} & \multicolumn{2}{c}{$\mathbf{2 0 1 6}$} & \multicolumn{2}{c}{$\mathbf{2 0 1 8}$} & \multicolumn{2}{c}{$\mathbf{2 0 1 9}$} \\
\cline { 2 - 13 } & rank & \% & rank & \% & rank & \% & rank & \% & rank & \% & rank & \% \\
\hline Germany & I & 26 & II & 15 & I & 21 & & & III & 9 & I & 19 \\
USA & II & 19 & I & 16 & & & II & 17 & I & 17 & II & 13 \\
Poland & III & 12 & & & III & 10 & & & III & 9 & & \\
Great Britain & & & & & & & III & 11 & & & & \\
Canada & & & II & 15 & II & 13 & I & 21 & II & 10 & III & 10 \\
EU countries & & 4 & & 4 & & 0 & & 3 & & 3 & & 2 \\
$\begin{array}{l}\text { Don't know / country } \\
\text { wasn't specified }\end{array}$ & & 10 & & 12 & & 9 & & 13 & & 24 & & 16
\end{tabular}

Source: survey data, 2013-2016, 2018-2019. The table shows only those countries that have received the first three ranks of significance. Ranks of significance are defined by the frequency of the choice received. 
Table 3. The most attractive countries for potential long-term migrants, $\%$ of the respondents who would move abroad for a few years

\begin{tabular}{|c|c|c|c|c|c|c|c|c|c|c|c|c|}
\hline \multirow[t]{2}{*}{ Answers } & \multicolumn{2}{|c|}{2013} & \multicolumn{2}{|c|}{2014} & \multicolumn{2}{|c|}{2015} & \multicolumn{2}{|c|}{2016} & \multicolumn{2}{|c|}{2018} & \multicolumn{2}{|c|}{2019} \\
\hline & rank & $\%$ & rank & $\%$ & rank & $\%$ & rank & $\%$ & rank & $\%$ & rank & $\%$ \\
\hline Germany & II & 11 & II & 13 & II & 14 & II & 11 & II & 9 & I & 14 \\
\hline USA & I & 16 & I & 22 & I & 16 & I & 16 & I & 19 & & \\
\hline Poland & II & 11 & III & 6 & III & 10 & III & 10 & & & & \\
\hline Great Britain & & & & & & & & & III & 7 & III & 6 \\
\hline Canada & III & 10 & III & 6 & & & & & & & II & 8 \\
\hline Italy & & & & & & & & & II & 9 & & \\
\hline EU countries & & 6 & & 7 & & 5 & & 6 & & 2 & & 6 \\
\hline $\begin{array}{l}\text { Don't know / } \\
\text { country wasn't } \\
\text { specified }\end{array}$ & & 26 & & 23 & & 16 & & 24 & & 40 & & 32 \\
\hline
\end{tabular}

Source: survey data, 2013-2016, 2018-2019. The table shows only those countries that have received the first three ranks of significance. Ranks of significance are defined by the frequency of the choice received.

Great Britain took the third position just in three years: as a destination country for potential stationary migrants in 2016, and for long-term migrants in 2018 and 2019. In 2018, Italy shared with Germany the second position in the ranking of countries where they would go for a long time. The most attractive country for people who would go for temporary work abroad was Poland (Table 4). It received the largest number of choices among this category of respondents in almost all years of study and took the first rank of significance respectively. In addition, Germany, the USA, and Spain also became the attractive countries for potential temporary workers. Some countries were frequently chosen in only one of the six studied years. Thus, in 2016 Great Britain shared the third ranking position with Germany; Sweden took the second ranking position in 2015, and the Czech Republic did so in 2018. According to the worldwide survey, USA Germany and Canada are the most attractive countries for potential foreign workers (Strack et al., 2018). In our study these countries are also desirable, but Poland took the first place, because Lviv is a region bordering on this country.

It's worth noting that a significant part of the survey participants (from $9 \%$ up to $56 \%$ of those who gave an affirmative answer to the question) did not write in a single country. The persons, who would go for temporary work abroad, did not indicated destination country the most often and potential stationary migrants did so the least.

Table 4. The most attractive countries for potential temporary migrants, $\%$ of the respondents who would move abroad temporarily

\begin{tabular}{|c|c|c|c|c|c|c|c|c|c|c|c|c|}
\hline \multirow{2}{*}{ Answers } & \multicolumn{2}{|c|}{2013} & \multicolumn{2}{|c|}{2014} & \multicolumn{2}{|c|}{2015} & \multicolumn{2}{|c|}{2016} & \multicolumn{2}{|c|}{2018} & \multicolumn{2}{|c|}{2019} \\
\hline & rank & $\%$ & rank & $\%$ & rank & $\%$ & rank & $\%$ & rank & $\%$ & rank & $\%$ \\
\hline Germany & II & 11 & II & 7 & & & III & 7 & III & 4 & I & 20 \\
\hline USA & I & 19 & II & 7 & III & 9 & II & 17 & & & & \\
\hline Poland & I & 19 & I & 21 & I & 26 & I & 26 & I & 14 & II & 16 \\
\hline Great Britain & & & & & & & III & 7 & & & III & 8 \\
\hline Canada & II & 11 & & & & & & & & & & \\
\hline Spain & III & 8 & II & 7 & & & & & & & & \\
\hline Sweden & & & & & II & 12 & & & & & & \\
\hline Czech Republic & & & & & & & & & II & 11 & III & 8 \\
\hline Italy & & & III & 5 & & & & & & & & \\
\hline EU countries & & 7 & & 5 & & 9 & & 2 & & 0 & & \\
\hline $\begin{array}{l}\text { Don't know / country } \\
\text { wasn't specified }\end{array}$ & & 22 & & 37 & & 23 & & 32 & & 56 & & 31 \\
\hline
\end{tabular}

Source: survey data, 2013-2016, 2018-2019. The table shows only those countries that have received the first three ranks of significance. Ranks of significance are defined by the frequency of the choice received. 
Then, in order to identify the share of those, who had migration plans the question "Are you planning to be employed abroad in the nearest 5 years?" was asked. Analysis of answers for the six years under research shows that they are different (Figure 2). So the smallest number of respondents planning to be employed abroad was in 2014 (only 14\%) and the largest - in $2015(27 \%)$. The share of unemployed who gave positive answer to this question has not changed for the last two years (2018 and 2019) and made up almost one-quarter of all surveyed.

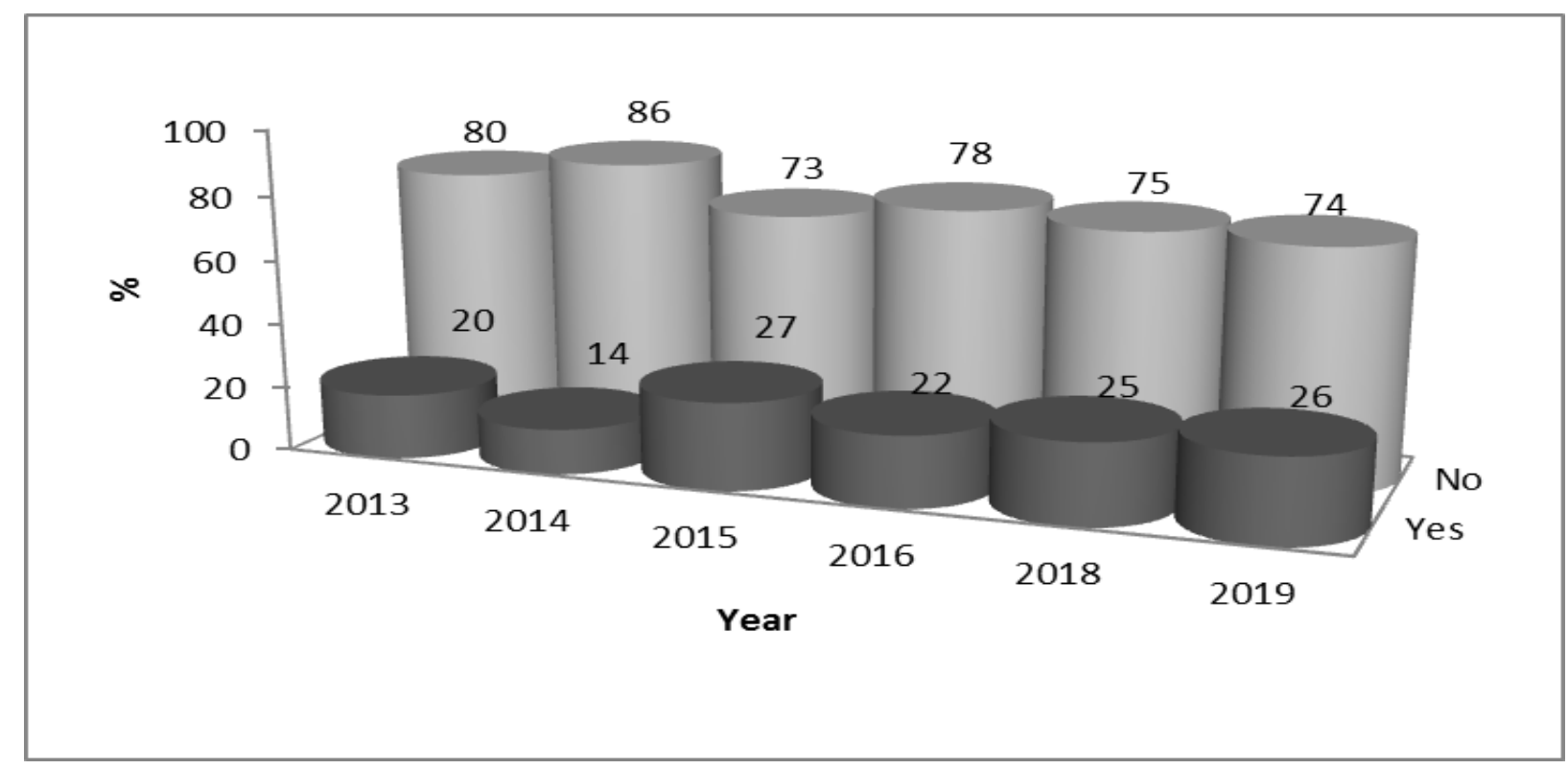

Figure 2. Migration plans of unemployed, in $\%$ of the respondents

Source: survey data, 2013-2016, 2018-2019.

Only at the last stage of a panel survey (in 2019) the question about migration preparations was asked. The share of respondents who confirmed their preparation for the migration plans realization was 18\%. Thus in 2019 the share of those who had positive migration desires was $56 \%$, the group of those who really planned to move abroad made up $26 \%$ and only $18 \%$ of respondents showed readiness to migrate. The results of Gallup World Pull show that ratio of these three groups of potential migrants to each other is higher than in our study. So, according to Gallup's survey almost the third part of people planning to migrate permanently have made some preparation to move (Laczko et al. 2017, p.3). Among the unemployed the ratio of these two groups made up two thirds. The main reason for this is that we surveyed a specific group of population - unemployed persons. Besides, the questions formulating is also different. In the case of Gallup's survey a permanent potential migration was investigated. In the case of unemployed it was about labor migration.

In order to investigate the influence of the socio-demographic characteristics of a person on his/her decision regarding employment abroad logistic regression have been constructed. To calculate the regression parameters, we used the Analyze module of the IBM SPSS Statistics program, where the dependent variable is encoded: 0 - "the respondent does not plan to go abroad to work", 1 - "the respondent plans to go abroad to work". According to the "Forward: LR (Direct: Maximum Likelihood)" method, variables were introduced into the equation step by step, starting from those that have the greatest influence on the dependent variable, and ending with the one that have the weakest influence.

At the first stage, the variable "gender" was introduced into the model, and at the second - the "age" of the respondent (Table 5). "Educational level" and "marital status" were also planned to be introduced, however, statistical tests did not confirm the significance of the influence of these variables on the effective variable. 
Table 5. Logistic regression of willingness to work abroad depending on gender and age

\begin{tabular}{|c|c|c|c|c|c|c|c|}
\hline & & B & S.E. & Wald & df & Sig. & $\operatorname{Exp}(B)$ \\
\hline \multirow[t]{2}{*}{ Step $1^{\mathrm{a}}$} & Gender_female & -1.414 & 0.264 & 28.551 & 1 & 0.000 & 0.243 \\
\hline & Constant & 1.045 & 0.404 & 6.954 & 1 & 0.004 & 2.843 \\
\hline \multirow[t]{3}{*}{ Step $2^{b}$} & age_$>35 \mathrm{p}$. & -0.485 & 0.176 & 7.536 & 1 & 0.003 & 0.616 \\
\hline & Gender_female & -1.558 & 0.276 & 31.574 & 1 & 0.000 & 0.210 \\
\hline & Constant & 2.125 & 0.652 & 13.724 & 1 & 0.000 & 8.369 \\
\hline
\end{tabular}

a. Variable(s) entered on step 1: Gender.

b. Variable(s) entered on step 2: age.

Source: calculated by the authors according to the results of the one of the stages (2018) of a panel survey of the unemployed population of Lviv region

Regression equation is as follows:

$$
\mathrm{P}=\frac{1}{1+\mathrm{e}^{0.485 \mathrm{~m}_{1}+1.558 \mathrm{~m}_{2}-2.125}}
$$

where $\mathrm{x}_{1}$ - age, $\mathrm{x}_{2}$ - gender of a respondent.

The last column of the table 5 is calculated as antilogarithms to the regression parameters (Exp (B)) and reflects the correlation of the chances of the presence of migration plans of the studied groups (OR - odds ratio). So, from model 2 of the table 5 it follows that the ratio of such chances between females and males makes 0.2 . It means the chance that a woman will go abroad is 5 times less (with constant age parameters). Regarding age, the chance that a person over 35 years will plan to work abroad is about $40 \%$ lower than for young people (for people of the same gender). The values of Cox \& Snell R-Square $=0.606$ and Nagelkerke R-Square $=0.657$ coefficients show that the probability of going abroad to work between 60 and $65 \%$ can be explained by the respondent's gender and age.

To assess the predictive ability of the model, we constructed a ROC-curve (Receiver-Operator Characteristic) (Figure $3)$.

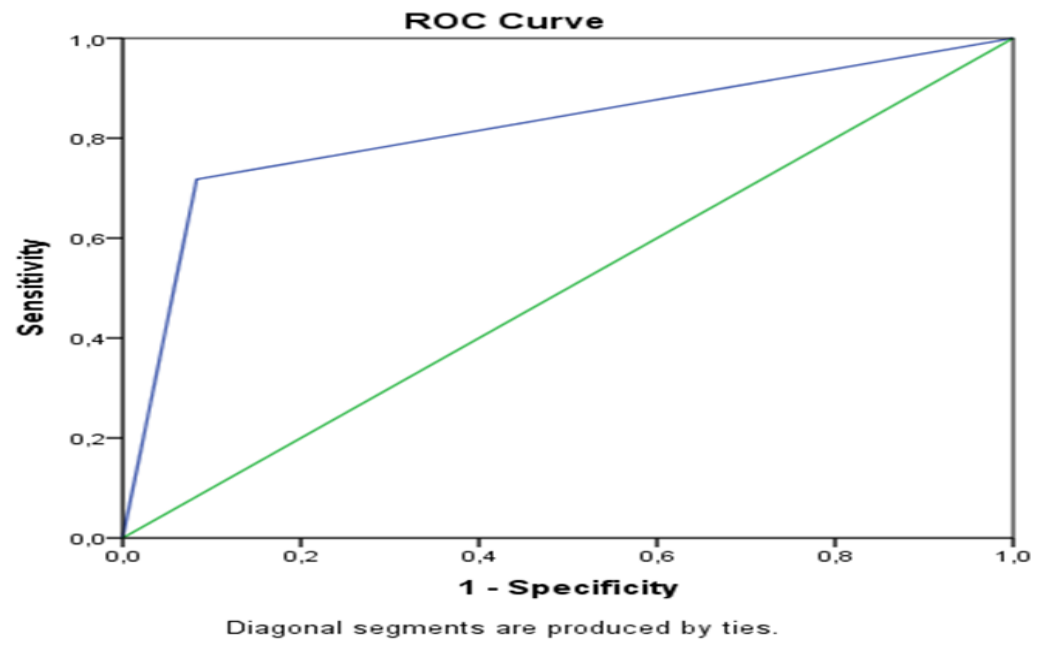

Figure 3. ROC-curve of the logistic model of the regression of willingness to work abroad for residents of Lviv region, depending on gender and age

Source: compiled by the authors according to the results of a survey of the unemployed population of Lviv region (in 2018) 
The quality of classification is determined by the area of the figure under the ROC curve, which is denoted as AUC (area under curve). It is known that the higher value of the AUC is, the higher is the predictive value of the model. In this case, the following model quality characteristic is used: from 0.9 to 1.0 - excellent classification quality, from 0.8 to 0.9 - very good, from 0.7 to 0.8 - good, from 0.6 to 07 - average, from 0.5 to 0.6 - unsatisfactory. The classification threshold (cut-off point) is selected arbitrarily. In our task, AUC $=0.817$, which indicates a high predictive ability of the model.

For a more comprehensive, in-depth assessment and to obtain more complete information about the possible scale of external migration of the population, we consider it appropriate to use not only direct indicators of the potential migration, but also auxiliary ones. Respondents' value judgments regarding their financial situation and future perspectives can serve as one of such parameters. Dissatisfaction with financial situation and lack of opportunities and hopes for employment, career development and self-realization in Ukraine is what often provokes people to migrate abroad. Thus, the results of panel survey of unemployed conducted by us revealed little to no percent of people, who estimate financial condition of their family to be high or higher than average (Table 6). The most often it was estimated as average by the respondents during the whole period under research (i.e. annually category "average" was the mode for the variable «financial condition»). Situation was the worst in 2015, when none of the respondents defined their financial situation as high, however $10 \%$ of them estimated it as very low and almost fourth part of them - as low.

Table 6. Respondents' estimation of their families' financial situation

\begin{tabular}{|c|c|c|c|c|c|c|c|}
\hline \multirow[t]{2}{*}{$\begin{array}{l}\text { Level of the material } \\
\text { condition }\end{array}$} & \multirow{2}{*}{$\begin{array}{c}\text { Estimation } \\
\text { of financial } \\
\text { situation in } \\
\text { points, } \\
b_{i}\end{array}$} & \multicolumn{5}{|c|}{$\begin{array}{l}\text { Share of respondents, who estimate financial situation of their families } \\
\text { to be at the i level, } \% \text {, }\end{array}$} & families \\
\hline & & 2013 & 2014 & 2015 & 2016 & 2018 & 2019 \\
\hline High & 6 & 1.1 & 0.8 & 0 & 0.9 & 0.3 & 1.1 \\
\hline Higher than medium & 5 & 3.1 & 2.8 & 3.2 & 4.1 & 2.1 & 5.2 \\
\hline Medium & 4 & 43.1 & 46.8 & 40.4 & 42.6 & 53.3 & 54.9 \\
\hline Lower than medium & 3 & 25 & $24 ., 5$ & 22.1 & 27.8 & 24.3 & 22.4 \\
\hline Low & 2 & 20.3 & 18 & 24.4 & 20.3 & 12.7 & 14.6 \\
\hline Very low & 1 & 7.5 & 7.3 & 10 & 4.3 & 7.4 & 1.8 \\
\hline $\begin{array}{l}\text { Average ordinal } \\
\text { score* }^{*}\end{array}$ & - & 3.18 & 3.23 & 3.03 & 3.25 & 3.31 & 3.5 \\
\hline $\begin{array}{l}\text { Average centered } \\
\text { score }^{* *}\end{array}$ & - & -0.32 & -0.27 & -0.47 & -0.25 & -0.19 & $\mathbf{0}$ \\
\hline
\end{tabular}

Source: own calculations based on survey data.

*Average ordinal score is calculated according to the formula:

$$
\left(\sum_{i=1}^{6} b_{i} \times d_{i}\right) / \mathbf{1 0 0} \%,
$$

where bi - estimation of financial situation in points; di - share of respondents, who estimate financial situation of their families to be at the i level.

**Average centered score - the difference between the average ordinal score and the half-sum of maximum and minimum points (Kramchenko, 2007, p.138).

In order to analyze the dynamics of financial situation of unemployed population in Lviv we have calculated the grade point average of estimations for each year under research according to 6-point scale, where 6 corresponds to 
high level and 1 - to very low (Table 6). Performed calculations showed that average level of respondents' financial situation was the lowest in 2015. It confirms the abovementioned conclusion about the critical situation this year. It is worth mentioning that in 2015 we also revealed the highest share of potential labor migrants (see Figure 2). Instead, in 2014 the level of financial situation (according to respondents' subjective estimations) was somewhat higher, while migration mindset was rather low.

Estimation of employment opportunities in Ukraine by unemployed is another important factor of their migration mindset forming. The results of six-year monitoring reveals sufficiently small percent of unemployed, who estimate their chances at national labor market as very good (Table 7). It was the highest in 2016 and amounted to 5,5\%, and the lowest $-2,6 \%$ in 2015. Every fifth respondent saw his/her chances as bad (mostly persons older than 50). However, for the most part the respondents defined their opportunities as satisfactory (36\% - 41\%) and good (25\% $31 \%)$. So, in conclusion majority of respondents see their chances at national labor market as positive.

Table 7. Respondents' estimation of their employment opportunities in Ukraine

\begin{tabular}{|c|c|c|c|c|c|c|c|}
\hline \multirow{2}{*}{$\begin{array}{l}\text { Employment } \\
\text { opportunities }\end{array}$} & \multirow{2}{*}{$\begin{array}{c}\text { Estimation } \\
\text { of } \\
\text { employment } \\
\text { opportunities } \\
\text { in points, } \\
\boldsymbol{b}_{\boldsymbol{i}}\end{array}$} & \multicolumn{6}{|c|}{$\begin{array}{l}\text { Share of respondents, who estimate their employment opportunities to be } \\
\qquad \text { at the } i \text { level, \%, }\end{array}$} \\
\hline & & 2013 & 2014 & 2015 & 2016 & 2018 & 2019 \\
\hline Very good & 6 & 4.7 & 4.3 & 2.6 & 5.5 & 3 & 8.3 \\
\hline Good & 5 & 24.8 & 30.8 & 30 & 28.6 & 21.6 & 22.9 \\
\hline $\begin{array}{l}\text { Satisfactory } \\
\text { (medium) }\end{array}$ & 4 & 39.8 & 36.8 & 35.7 & 41.1 & 50.6 & 49 \\
\hline Bad & 3 & 21.2 & 21.5 & 21.7 & 18.4 & 21.3 & 17.7 \\
\hline Very bad & 2 & 8.4 & 5.3 & 8.9 & 5 & 3 & 1.6 \\
\hline Absent & 1 & 1.1 & 1.5 & 1.1 & 1.5 & 0.6 & 0.5 \\
\hline Average score* & - & 3.93 & 4.04 & 3.93 & 4.07 & 3.99 & 4.17 \\
\hline
\end{tabular}

Source: own calculations based on survey data.

*Average score is calculated according to the formula:

$$
\left(\sum_{i=1}^{6} b_{i} \times d_{i}\right) / \mathbf{1 0 0 \%}
$$

where bi - estimation of employment opportunities in points; di - share of respondents, who estimate their employment opportunities to be at the i level.

Calculation of grade point average of respondents' answers per each year didn't show significant changes in their estimations. Thus, the highest was the result in 2019 and amounted to 4.17 points, the lowest - in 2013 and 20153.93 points. Therefore, in the period under research the respondents saw their employment opportunities as satisfactory. Instead, the views over the overall situation at national labor market were not so optimistic; in particular it concerns the view of its improvement perspectives (Figure 4). 


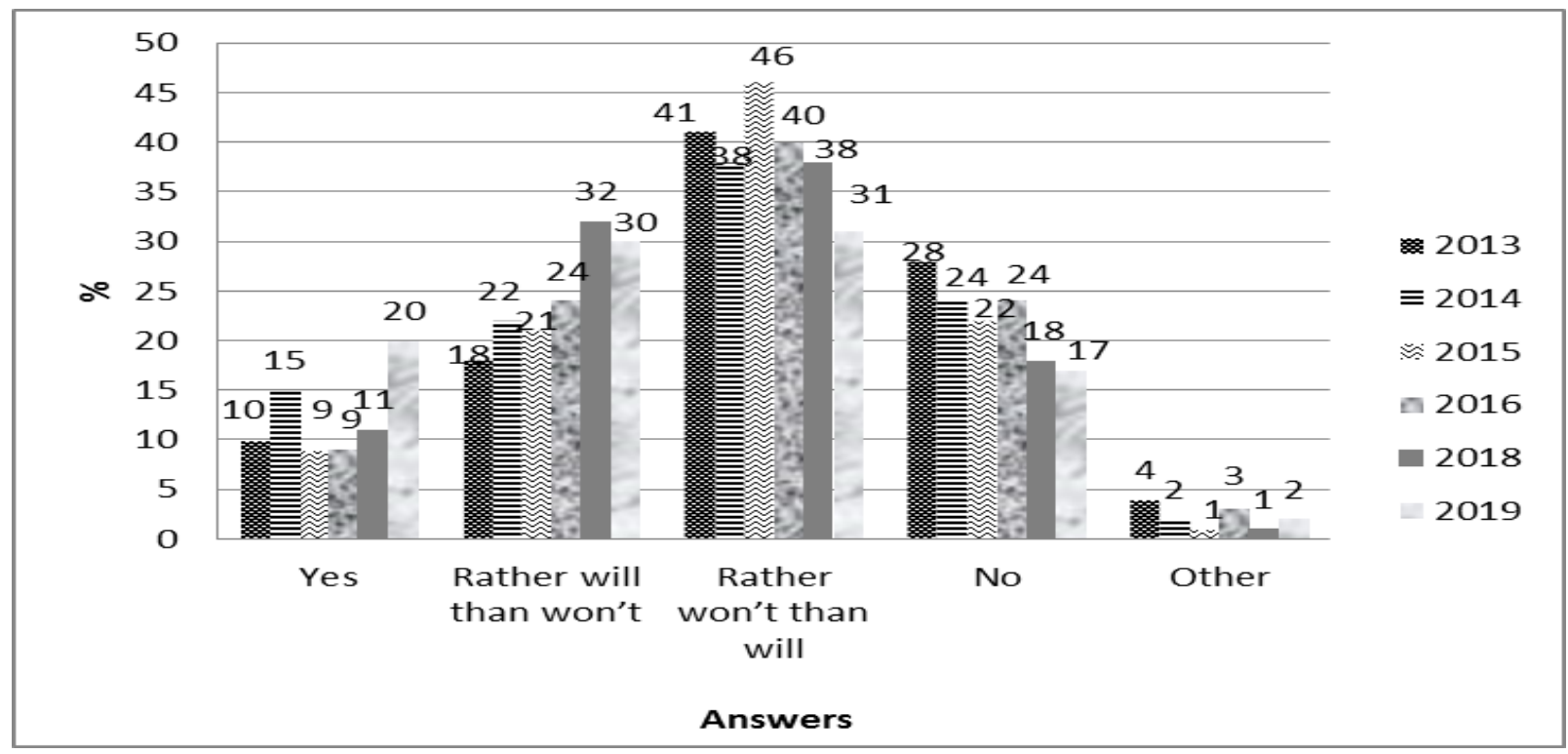

Figure 4. Answers to the question «In your opinion, will the employment opportunities in Ukraine improve in the nearest year?», in \% of the respondents (2013-2016, 2018-2019)

The Figure 4 shows that option «rather won't than will» had the largest selection frequency (responses vary within $31 \%$ - 46\%). Almost fourth part of respondents annually completely negatively estimated the development tendencies at labor market in Ukraine. The largest number of «solidly» positive responses was received in 2019 amounting to $20 \%$ of respondents. Instead, solidly negative estimation of employment opportunities in Ukraine for the nearest future was most often selected in 2013 (28\%).

Now we examine the relationship between the existing of migration plans of the unemployed and their assessment of their employment opportunities in Ukraine. According to the results of the 2019 survey we have got the test statistic $\chi^{2}=27.485$, which exceeds critical value $\mathrm{k}=11.07(\mathrm{df}=5, \dot{\alpha}=0.05)$. So we reject null hypothesis. It means that there is a statistical relationship between these two variables. In particular, most of those, who estimate their opportunities on the national labor market as very good, good and satisfactory (average) don't have plans to be employed abroad (Table 8). At the same time almost half part of respondents who consider that their opportunities are bad have such plans. It was too few persons who answered "very bad" and "bad", so analyzing of their answer may be incorrect.

Table 8. Migration plans depending on estimation of employment opportunities, $\%$ of each group of respondents

\begin{tabular}{lccccccc}
\hline \multirow{2}{*}{ Migration plans } & \multicolumn{2}{c}{ Share of respondents, who estimate their employment opportunities as: } & \multirow{2}{*}{ Total } \\
& Very good & Good & Average & Bad & Very bad & Absent & \\
\hline Yes & 18.8 & 21.6 & 19.7 & 47.1 & 33.3 & 100 & 26 \\
No & 81.2 & 78.4 & 80.3 & 52.9 & 66.7 & 0 & 74 \\
Total & $\mathbf{1 0 0}$ & $\mathbf{1 0 0}$ & $\mathbf{1 0 0}$ & $\mathbf{1 0 0}$ & $\mathbf{1 0 0}$ & $\mathbf{1 0 0}$ & $\mathbf{1 0 0}$ \\
\hline
\end{tabular}

Source: survey data, 2019

\section{Conclusion}

The survey allows determining different types of potential migrants: those who have migration desires; those who have migration plans and those who make some preparation for movement in addition. The distinguishing of these three groups of potential migrants helps better understanding of results of potential migration researches and avoids speculation on this subject in mass media. Additionally it serves a basis for elaboration of appropriate measures of migration and labor market policy, taking into account each group of potential migrants. The results confirmed our hypothesis that the share of respondents decreases approaching to the stage of migration plans realization.

Presented in this article maps of migration preferences of different groups of potential migrants can be used in future 
researches. It will help to identify main destination countries of migration flows and to elaborate better cooperation with them.

More comprehensive analysis of potential migration was obtained by using some respondents' subjective assessments. Statistical tests confirmed our hypothesis about the dependence of the migrant preferences of the unemployed on their assessment of their employment opportunities in Ukraine The study shows that the most optimistic estimates of respondents' financial situation and opportunities on the national labor market correlate with lower level of potential migration. So improving earnings and employment opportunities on the national labor market is one of the ways to prevent human potential losses.

The findings of this study have to be seen in light of some limitations. The first concerns the participants of the survey - unemployed persons - visitors of the Lviv City Employment Center. We could obtain another results if we had access to another group of unemployed - those, who didn't seek employment assistance. The second limitation is the feature of the place of the survey. Lviv is a border region, transit zone and the main territory of migrants' origin. So some results may not be generalized to all regions of Ukraine. In this regard prospects for further research are: to conduct surveys representative for all the population of the region and in other regions; to make the comparative analysis of potential migration between different social-economic groups and between different regions of Ukraine or countries.

\section{References}

Blinova, O. (2011). Labour migration of population of Ukraine in the socio-psychological dimension. Kherson: RIPO.

Carling, J. (2002). Migration in the age of Involuntary Immobility: Theoretical Reflections and Cape Verdean Experiences. Journal of Ethnic and Migration Studies, 28(1), 5-42.

Carling, J., \& Collins, F. (2018). Aspiration, desire and drivers of migration. Journal of Ethnic and Migration Studies, 44(6), 909-926. https://doi.org/10.1080/1369183X.2017.1384134

Denisenko, M., Yontsev, V., \& Khorev, B. (1989). Migratsiology. Moscow: MGU.

Edo, A. (2019). The impact of immigration on the labor market. Journal of Economic Surveys, 33(3), 922-948. https://doi.org/10.1111/joes.12300

Esipova, N., Pugliese, A., \& Ray, J. (2018). More than 750 million worldwide would migrate if they could. Gallup. Retrieved from https://news.gallup.com/poll/245255/750-million-worldwide-migrate.aspx

Esipova, N., Ray, J., \& Srinivasan, R. (2011). The World's Potential Migrants. Who They Are, Where They Want to Go, and Why it Matters. Gallup. Retrieved from https://www.migrationinstitute.org/files/events/gallup_whitepaper_migration.pdf

Fujita, Y. (2018). Does "Higher Wall" Hinder Immigration?. Research in World Economy, 9(1), 34-38. https://doi.org/10.5430/rwe.v9n1p34

Gheasi, M., \& Nijkamp, P. (2017). A Brief Overview of International Migration Motives and Impacts, with Specific Reference to FDI. Economies, (5), 31. https://doi.org/10.3390/economies5030031

Grencíková, A., \& Spanková, J. (2016). Labour Migration Trends in the Slovak Republic. Economics and Sociology, (9), 158-67. https://doi.org/10.14254/2071-789X.2016/9-2/11

Gubert, F., \& Jean-Noël, S. (2016). Is the European Union attractive for potential migrants? An investigation of migration intentions across the world. OECD Social, Employment and Migration Working Papers, No. 188, OECD Publishing, Paris. https:/doi.org/10.1787/5jlwxbv76746-en

Gubert, F., \& Nordamn, C. J. (2009). The Future of International Migration to OECD Countries. Regional note. North Africa. Paris, France. Retrieved from https://www.oecd.org/futures/43484295.pdf

King, R., \& Gëdeshi, I. (2019). New trends in potential migration from Albania: the migration transition postponed?. Migration and Development. https:/doi.org/10.1080/21632324.2019.1608099

Kramchenko, L. I. (2007). Statistics of Market for Goods and Services. Lviv: New World-2000.

Krutova, O. (2019). Immigrants' contribution and share: multilevel analysis of migrant labour contribution to productivity, welfare and income in Finland. Economics and Sociology, 12(4), 21-42. https:/doi.org/10.14254/2071-789X.2019/12-4/1

Laczko, F., Jasper, T., \& Daniel, A. (2017). Measuring Global Migration Potential, 2010-2015. Data Briefing Series 
of IOM's Global Migration Data Analysis Centre. IOM's Global Migration Data Analysis Centre: Berlin. Retrieved from https://publications.iom.int/system/files/pdf/gmdac_data_briefing_series_issue_9.pdf

Libanova, E. (2019). Labour migration from Ukraine: Key features, drivers and impact. Economics and Sociology, 12(1), 313-328. https:/doi.org/10.14254/2071-789X.2019/12-1/19

Marchuk, A. V. (2011). Causes and Main Motives of Labor Migration in the World and Ukraine. Retrieved from http://www.confcontact.com/20110629/1_marchuk.php

Migali, S., Natale, F., Tintori, G., Kalantaryan, S., Grubanov-Boskovic, S., Scipioni, M., ... Barbas, T. (2018). International Migration Drivers, EUR 29333 EN, Publications Office of the European Union, Luxembourg. Retrieved from http://publications.jrc.ec.europa.eu/repository/handle/JRC112622

Minfin - Ministry of Finance of Ukraine. (2019). Unemployment rate in Ukraine. Retrieved from https://index.minfin.com.ua/ua/labour/unemploy/2019/

Ringdal, K. (2007). Enhet og mangfold. 2. utgave. Bergen: Fagbokforlaget.

Rybakovsky, L. (2001). Migration of the population. Three stages of the migration process. Essays on theory and research methods. Moscow: Science.

Ryndzak, O. (2016) Theoretical and methodological foundations of migration processes researches. Formation strategy of economic structures: the tools and practices: Collective monograph. Edited by A. Berezin, M. Bezpartochnyi. Riga: "Landmark" SIA, 82-90. Retrieved from http://www.lnau.edu.ua//nau/attachments/3361_contents.pdf

Ryndzak, O. (2019). Evaluation of a population's migration potential as an important component of migration policy. Economies, 7(3), 72. https:/doi.org/10.3390/economies7030072

Skog, O-J. (2010). A forklare sosiale fenomener. En regresjonsbasert tilnarming. Oslo: Gyldendal Akademisk.

SSSU - State Statistics Service of Ukraine. (2020). Official Site. Average Monthly Wages by Type of Economic Activity since the Beginning of the Year. Archive. Retrieved from http://www.ukrstat.gov.ua/

Strack, R., Booker, M., Kovács-Ondrejkovic, O., Antebi, P., \& Welch, D. (2018). Decoding global talent 2018. Retrieved from https://www.bcg.com/publications/2018/decoding-global-talent.aspx

Sumption, M., \& Somerville, M. (2009) Immigration and the Labour Market: Theory, Evidence and Policy. Migration Policy Institute reports, March. Retrieved from https://www.migrationpolicy.org/research/immigration-and-labour-market-theory-evidence-and-policy

United Nations, Department of Economic and Social Affairs. Population Division. (2019). International Migration Stock 2019: Graphs. Twenty Countries or Areas of Origin with the Largest Diaspora Populations (millions). UN: New York. Retrieved from https://www.un.org/en/development/desa/population/migration/data/estimates2/estimatesgraphs.asp?3g3

Vandenbroucke, G., \& Zhu, H. (2017). Mixing the Melting Pot: The Impact of Immigration on Labor Markets. Regional Economist. Retrieved from https://www.stlouisfed.org/publications/regional-economist/first_quarter_2017/mixing-the-melting-pot-the-impa ct-of-immigration-on-labor-markets 